\section{Instinct of Magpies}

I HAVE read in NATURE (p. 428) your correspondent's letter relative to the instinct shown by magpies in Scotland as to the time for commencing their nest-building, which goes so far as to assume that this particularly cunning bird is capable of fixing a certain day in March (the Sunday after the 16 th as I remember) as the invariable time to start the nest. And the writer observes that it would be well to ascertain if difference of latitude made any difference in the magpies' calculation. Now I live in the south-east of Ireland, a good many degrees south of your correspondent's Scotch magpies' locality, and it so happens that I have for the last twenty years observed the nest-building of magpies, who have enjoyed undisturbed possession, and who invariably build in the trees close to my house. It is curious that this colony (if a single pair may so be called) never increases-four young "mags" are brought out every year-but though I have observed congregations of ten or fourteen at times, the breeding birds never exceed two. The young birds never, like rooks, join a colony near their paternal nests, but are shipped off to new localities. I could mention many traits of my magpies' instinct-" their tricks and their manners"-but will confine myself to the nest-building. They never repair or reoccupy an old nest. A new one is constructed every year, and always, each year, in a different tree. Their nest-building is a serious labour, and takes a long time. So they begin early in February, selecting the sites often with much deliberation. The work is entered on very early in the morning, and the "mags" seldom work in the daytime. About the end of March this domed nest with its two openings is finished, and the laying of eggs commenced. I am quite certain that the middle of March is not the time of beginning the nest, and this is important, as the claim set up for the magpies instinctive knowledge of dates therefore falls to the ground. I do not conceive it possible to prove that in this particular magpies have a more highly developed instinct than most other birds; all have their normal time of nesting, although there may be cases of abnormally late or early building; but as to the magpies or any other bird being able to fix dates exactly to the day, it is unproved and incredible.

Inisnag, Stonyford, Co. Kilkenny

JAMES GRAVES

\section{Cats at Victoria Station}

THAT the cats should repose comfortably amidst all the noise and vibration of a busy railway is not, after all, to be much wondered at. Animals much more defenceless and timid have found out that they need not be afraid of either the vibration or the trains, although they do not seem to have discovered that if they get in the way of the trains they are either maimed or killed. For instance, along the London and North-Western Railway between Manchester and Liverpool, which carries an enormously heavy traffic, rabbits burrow almost immediately beneath the ballast forming the permanent way, and I have often seen them sitting nearer to the train than most human beings would like to stand. It is strange, however, that along this line of railway, which is one of the oldest in England, neither the rabbits nor the grouse and partridges have learnt that, though the train is not to be dreaded as a man is dreaded, it is usually fatal to those who are struck by it. All these creatures, as well as hares, pheasants, \&c., are constantly being run over by passing trains. A hen grouse or partridge will frequently take her brood on to the railway, no doubt for the purpose of dusting themselves, and meet with this fate. The survivors, however, do not seem to take warning by the occurrence. The same may be said of the telegraph-wires, against which the birds are constantly flying. The number killed in this way is considerable. This is the more remarkable because along this line wild animals have had such a lengthened experience of rail and wire that one would suppose it might have taught them wisdom.

RoOKe: PeñINGTON

\section{Wild Duck laying in Rook's Nest}

With reference to Mr. Willmore's note in NATURE (p. 573), I have met with several instances in Lincolnshire of wild ducks nesting at a considerable height above the ground-once in an oak in a plantation in the old nest of a carrion crow-in ivy on a ruined wall, and on the top of a straw stack; once also on the roof of an old bean stack in the marches. I have known a wild duck nest on the ground amongst brambles and rough grass in the centre of a plantation a mile or more from pond or running stream.

Junior Athenæum Club, April 2I

\section{Science and the Public Service}

THE public are greatly indebted to your correspondent for drawing attention in NATURE of March 27 (p. $5 \mathrm{II}$ ) to the astounding proposal of the War Office to adopt the scheme of examination described by Lord Morley in the House of Lords on March 27-a scheme so absolutely retrogressive, and opposed to the recommendations of the Public School Commission of 1862 and of the Commission on Scientific Instruction in $1872(\mathrm{com}-$ posed of many eminent men and presided over by the Duke of Devonshire), and to the rapidly strengthening opinion in favour of education in science. The Government must be asked to withdraw the scheme.

Whittington, Chesterfield, April I6

\section{THE HONG KONG OBSERVATORY}

I. $\mathrm{T}$ was found to be impossible to select a suitable site for the new Observatory near the city of Victoria, as the mountains shut off from view a large section of the southern sky, extending up to $25^{\circ}$ of altitude. It is for the same reason impossible to determine the direction and velocity of the wind accurately near the town. Besides it is likely that the ferruginous rocks would deviate the plumb-line, not to mention the magnetic needles.

2. The Observatory was therefore built on the peninsula of Kaulung opposite. It stands on the top of Mount Elgin, a small hill built up of decomposed granite, rising abruptly on all sides from the surrounding level ground, and culminating in two humps distant over 300 feet from each other. The top of one of these is flat, and forms, roughly speaking, a circle of about 200 feet in diameter, and I Io feet above mean sea-level. Here the main building is situated, about 75 feet south-west of which the stands for the meteorological instruments, including the self-recording rain-gauge, are placed. It commands an unobstructed view of the sky, the tops of the hills rising only about seven degrees above the horizon. The magnetic hut is erected on the other prominence, the top of which was levelled, and forms a rectangle 36 feet by 30 feet.

3. The situation of the Observatory is rather secluded. It is surrounded by villas and summer residences; and the picturesque town rising opposite on the side of the steep mountain at a distance of a couple of miles, and the harbour, filled with the most bewildering mixture of menof-war and merchant ships belonging to nearly all nationalities, and literally swarming with boats and sampans, make up a charming view from the verandas of the Observatory, which, on the other hand, forms a prominent object as seen from the town and harbour.

4. I was appointed to take charge of the Observatory on March 2 last year, and when I arrived in the colony on July 28 , the foundations of the building had been already laid. It was then erected under my superintendence, and I was allowed to arrange every detail to suit the requirements. By January I the main building was so far finished that I could take up my residence there, and start tri-diurnal meteorological observations, and issue a daily weather report, containing also information concerning the direction and force of wind indicated by the gradients, based on telegrams received from the Treaty Ports, Manilla, and Nagasaki. I receive a telegram from Wladivostock in addition. The observations are made at 10 a.m. and at $4 \mathrm{p} . \mathrm{m}$. on the previous day.

5. The main building of the Observatory is a rectangular block, 83 feet long and 45 feet wide (not including the transit-room), the architecture of which does credit to the Surveyor-General's department. The upper floor is devoted entirely to my quarters. The ground floor com- 
prises four rooms, each 20 feet long, 16 feet wide, and 14 feet high. In the entrance hall is placed the telegraphic apparatus; to the right is my private office, where the library is placed, contained in glazed teak-wood bookcases, to protect the books from insects in the summer. I have already received extensive donations from scientific institutions in all parts of the world. The room next to this contains the clocks, which are fixed to brick piers neatly covered with teak wood. The piers, which rest on cement concrete, are carried down 6 feet below the ground in holes lined with bricks. Behind this is a small room in which the galvanic batteries are placed.

6. The mean-time clock, which is to discharge the timeball automatically, is furnished with a magnetic apparatus for setting to correct time without touching any part of the clock. The time-ball will be dropped at Tsim-sh'at-sui Point, opposite the harbour, about a mile from the Observatory. It is 6 feet in diameter. Opposite the meantime clock is the sidereal standard clock, which is of the most finished construction. It communicates by wire with a sympathetic dial placed in the transit-room. The face of the latter is black, and the hands and the figures are white, which I found very convenient at Markree Observatory, but unfortunately, Messrs. Dent and Co., who made all the horological apparatus, have omitted a second every minute. For marking a chronograph such an arrangement is most desirable, but it is rather awkward in observing with eye and ear. The clock-room contains the relays, and also one sidereal and two meantime chronometers.

7. The transit instrument, by Troughton and Simms, is placed in a wing room painted dark gray, I4 feet square and 14 feet high, next the clock-room. The meridian opening is I foot wide. The transit instrument has also a delicate level for observing zenith distances according to Talcott's method. The pivots are made of chilled bellmetal, a material which, I believe, was introduced to astronomical instrument-makers by Brinkley of Dublin, whose instruments remain serviceable up to this dav, while the pivots of transit instruments of much later date are corroded, being made of steel-a material that should not be used except where unavoidably necessary. An adjustable meridian mark is placed on a pier 66 feet north of the transit instrument. It is observed through a lens of that focal length, which is fixed in the meridian of ening of the transit-room.

8. To the left of the entrance hall is the general office and computing room, next to which is the room where the barometers, as well as the self-recording thermograph and barograph, are placed. Behind this is a small room that serves as a photographic laboratory. Every part of these two rooms, including ceilings, floors, and furniture is painted dark red, and there are only a few panes of glass in the windows, which are glazed with double red glass. The thermograph is supported by massive blocks of wood fixed on solid masonry, but the barograph is placed on a stand merely screwed to the floor. The screw that holds the self-registering thermograph is made of zinc.

9. Over the upper story of the building a turret rises 8 feet above the flat roof. This holds the self-recording parts of the anemometer, which is erected on top of it. The cups are 45 feet above the ground. The roof forms a convenient platform for making observations. The sunshine-recorder is placed in a groove in the coping-stone on the parapet, 34 feet above the ground. Lightning conductors are placed on the two chimneys. They rise a few feet higher than the anemometer.

I0. A one-storied block of outbuildings, containing servants' quarters and store-rooms, communicates with the main building by a covered passage.

II. The magnetic hut is I 7 feet long, I 3 feet broad, and the roof rises I I feet high. It is made of wood, painted pure white outside and inside. Bamboo chips instead of nails were used in its construction, as well as in that of the furniture. It has double doors, louvered and glazed, to the north and south, and two windows on either side, as well as two windows in the roof, which is convenient for reading the verniers. $\mathrm{C} n$ top of massive teak-wood blocks sunk $3 \frac{1}{2}$ feet in the ground and rising 4 feet above the floor are placed the dip-circle and the unifilar magnetometer. All the instruments were brought out safely, except the dipping needles, which appear not to have been sufficiently cleaned before packing. The hut is very comfortable, and forms therefore, in my opinion, a contrast to other structures used for making magnetic observations, in arranging which the importance of attending to the comfort of the observer in the hut is but too often lost sight of. The deviation is only 47 minutes easterly. The dip is 32 degrees (north end dipping). A broad road leads from the main building to the magnetic hut. This road is broken in the middle by a depression, across which a bridge will shortly be built.

12. Beside this road, at a distance of about 75 feet from the main building, it is intended to build a small house for the assistants, and near this has been selected the site for the refractor of 6 inches aperture, the loan of which I was promised by the Astronomer-Royal. That will complete the outfit.

$$
\text { W. DOBERCK }
$$

Hong Kong Observatory, March in

Government Astronorner

\section{THE CEDAR FOREST OF CYPRUS}

I I 879 Sir Joseph Hooker communicated to the Linnean Society ${ }^{1}$ the unexpected discovery of a form of the cedar of Lebanon (Cedrus libani var. brevifolia, Hook. f.) by Sir Samuel Baker in Cyprus.

The following extract from a letter lately received by the Director of the Royal Gardens, Kew, from Sir Robert Biddulph, K.C.M.G., C.B., the High Commissioner, gives a more detailed account of the forest, and will no doubt be interesting to many readers of NATURE :-

$$
\text { "Cyprus, March } 25
$$

"With regard to the cedars, I went last summer all through the thickest part of the forests, including the cedar forest, and I am able to give you some of the particulars you ask for, having noted them at the time. The cedar forest occupies a ridge on the principal watershed of the southern range, and about fitteen miles west of Mount Troodos. The length of the forest is about three miles, its breadth very much less. A few outlying cedartrees were visible on neighbouring hills, but on the ridge they were quite thick, and probably many thousands in number. I took the height above the sea by an aneroid barometer, and found it to be 4300 feet. The trees are very handsome and in good condition, but comparatively young. The smallest seemed to be from ten to fifteen years old ; the largest, I am told by the principal forest officer, are probably not over sixty or seventy years. The worst feature is that there were no seedlings or joung trees under ten years; and indeed this is the same with regard to the pine forests. It would seem as if the great influx of goats has been comparatively recent. I made a tour through the heart of the forest last August. I started from a point on the west coast, and from thence ascended to the main watershed, and kept along the top till I reached Mount Troodos, taking three days to do it. The country through which we passed on the first day was perfectly uninhabited, and a mass of hills and forest, chiefly Pinus maritima $[P$. halepensis] and the Ilex. The trees were in very great number, but there was a scarcity of young trees, and most of the old ones had been tapped for resin. On the second day we passed through the cedar forest, and the same sort of country as before, the Pinus Laricio beginning at an altitude of 4000 